\title{
Rezim Standar Industri Pariwisata dan Paradoks Pembangunan Desa Wisata: Pengalaman Desa Mangunan
}

\author{
Fatih Gama Abisono Nasution
}

\begin{abstract}
The structural perspective have explained well the paradox of development through the phenomenon of democratization in the trap of electoralism that does not change the inequality of power relations. This article moves in a different sense by offering the concept of governmentality in exploring the paradox of development. However, this study does not reject the argument that the paradoxical failure of development stems from the development mode that results in the depoliticization of development. The author deepens this argument by examining microscopically the types of power that work. More specifically, this study discusses the question of how the existing regime of knowledge about development produces paradoxical symptoms. Departing from the case of Mangunan Village, Bantul Regency, the findings in this study indicate that tourism development which was built in the name of a program to improve the welfare of the citizens in fact only serves the growth of the tourism industry. This can be seen from the knowledge regime that underlies the existence of the programs being carried out, namely encouraging the growth of the tourism industry that meets tourism business standards. This kind of knowledge regime is only possible for business actors who have access and resources to meet various tourism industry standards. Meanwhile, residents with limited resource capacity cannot meet various standards. In short, this kind of knowledge regime actually contributes to widening the gap in economic inequality between citizens.
\end{abstract}

Keywords

Development paradox; governmentality; knowledge regime; Tourist village; Mangunan

\section{Pendahuluan}

Kajian ini mendiskusikan paradoksal pembangunan di Yogyakarta yang secara khusus mengambil kasus di Desa Mangunan, Kecamatan Dlingo, Kabupaten Bantul.

Fatih Gama Abisono Nasution adalah Kadalah dosen di Sekolah Tinggi Pembangunan Masyarakat Desa APMD, Yogyakarta, Indonesia.

\section{Corresponding Author:}

Fatih Gama Abisono Nasution, Sekolah Tinggi Pembangunan Masyarakat Desa APMD, Yogyakarta, Indonesia.

Email: fatih.abisono@gmail.com 
Paradoksal tersebut berangkat dari situasi anomali yang tergambar dari berbagai indikator capaian pembangunan di Daerah Istimewa Yogyakarta (selanjutnya DIY) yang diteropong dari aspek kesejahteraan dan kualitas hidup masyarakat. Sebagaimana pandangan umum, kesejahteraan berbanding lurus dengan kualitas hidup masyarakat. Namun indikator capaian pembangunan DIY justru merefleksikan situasi sebaliknya. Kualitas hidup berbanding terbalik dengan gambaran kesejahteraan masyarakat DIY.

Dari sisi kualitas hidup warga DIY, dalam kurun 2014 hingga 2018, Indeks Pembangunan Masyarakat (IPM) DIY selalu berada diatas rata-rata angka nasional serta mengalami kenaikan rata-rata 0.65 setiap tahunnya (LKPJ Gubenur DIY 2018). Tahun 2018, IPM DIY mencapai 79,59, sedangkan IPM Nasional mencapai 71, 43. Bahkan pada tahun 2017, DIY menempati peringkat kedua provinsi dengan IPM tertinggi nasional. Kualitas hidup warga DIY juga diukur dengan Indeks Kebahagiaan (IK). Pada tahun 2017, IK DIY termasuk dalam kategori tinggi dengan nilai 72,93 dan serta melampai angka rata-rata nasional yaitu mencapai 70,69 (BPS 2018). Demikian pula Kementerian Desa pada tahun 2015 merilis Indeks Desa Membangun (IDM) yang menempatkan DIY pada angka 0.694 dalam kategori tinggi secara nasional.

Namun dibalik peningkatan kualitas kehidupan, aspek kesejahteraan masyarakat DIY terdeteksi mengalami stagnasi. Hal tersebut dapat ditunjukkan dari angka kemiskinan DIY yang berada di atas angka kemiskinan nasional. Data BPS menunjukkan, pada tahun 2017 angka kemiskinan DIY berada di angka $13,02 \%$ sedangkan angka kemiskinan nasional berada di angka 10,64 \%. Indikator lain tergambar dari ketimpangan kelompok pendapatan. Indeks Gini DIY pada tahun 2017 menunjukkan angka 0.440, lebih besar dibanding dengan ketimpangan nasional yaitu pada angka 0.391. Ketimpangan juga terlihat dari pembangunan antar wilayah yang diukur dengan Indeks Williamson. Pada tahun 2017 capain indeks tersebut menunjukkan, 0.4662. Hal ini menunjukkan tingginya ketimpangan antar wilayah di DIY. Data ketimpangan wilayah didukung pula dengan perbedaan angka kemiskinan dan capaian IPM antar kabupaten dan kota di DIY sangat mencolok antara Kota Yogyakarta dengan Kabupaten Gunung kidul.

Peningkatan kualitas hidup ternyata tidak berbanding lurus dengan kesejahteraan. Bahkan model pembangunan yang eksis justru menghasilkan kemiskinan dan ketimpangan. Sejauh ini respon Pemerintah DIY mempertanyakan metode pengukuran kemiskinan dan ketimpangan yang dikembangkan oleh BPS yakni dari sisi pengeluaran. Narasi yang dibangun terkait adanya keunikan faktor budaya yang membuat pengeluaran masyarakat DIY terpola hidup sederhana dan hemat (Republika 2017). Sedangkan ketimpangan terjadi karena masyarakat bawah yang hemat dibandingkan dengan konsumsi sebagian masyarakat ekonomi menengah ke atas yang mulai konsumtif.

Kajian ini bertujuan menawarkan penjelasan kritis terhadap paradoks pembangunan yang terjadi di DIY. Oleh karena itu, penulis memilih tidak berkubang pada argumen tentang polemik capaian indikator pembangunan beserta metode pengukurannya. Penulis menempatkan indikator tersebut sebagai symptom yang perlu diperdalam untuk menemukan pengetahuan baru tentang 
rezim pengetahuan pembangunan dengan karakter paradoksal. Berangkat dari studi kasus pembangunan di Desa Mangunan, artikel ini mendiskusikan pertanyaan tentang bagaimana rezim pengetahuan tentang pembangunan yang eksis menghasilkan symptom paradoksal. Dalam sepuluh tahun terakhir ini, Desa Mangunan banyak mengalami perubahan dan dikenal sebagai destinasi wisata baru. Penulis berargumen bahwa rezim pengetahuan yang berkembang adalah rezim pertumbuhan industri wisata yang justru berkontribusi memperlebar jarak ketimpangan antar warga.

Pembahasan dalam artikel ini dimulai dengan mendeskripsikan potret kajian tentang paradoks pembangunan. Setelah itu menjelaskan konsep governmentality yang menjadi kerangka kajian, serta uraian singkat lanskap sosial ekonomi Desa Mangunan. Diskusi dilanjutkan dengan membahas tata kelola Desa Wisata Mangunan dan profil kemiskinan yang melingkupinya. Dari potret kemiskinan yang ada, kemudian diungkapkan bahwa rezim pengetahuan pembangunan yang bekerja adalah rezim standar industri pariwisata, bukan rezim kesejahteraan warga. Diskusi diakhiri dengan menunjukkan implikasi rezim standar usaha pariwisata yang ternyata menghasilkan program-program pengembangan wisata yang tidak memiliki relasi kuat terhadap upaya penanggulangan kemiskinan.

\section{Literature Review}

\section{Paradoks Pembangunan: Sejumlah Perspektif Kritis}

Studi tentang paradoksal pembangunan, sejauh ini dijelaskan dengan perspektif struktural dalam mengupas ekonomi politik pembangunan. Sejumlah kajian kontemporer menyoroti paradoksal pembangunan terjadi karena absennya isu kekuasaan dalam mengelola pembangunan. Sebuah karya klasik oleh Ferguson (1994) menyodorkan kritik tentang bekerjanya "mesin anti politik" manakala pembangunan gagal menghantarkan kesejahteraan rakyat. Kritik Feguson didasari argumen pembangunan hanya menjadi instrumen teknikal ekonomi dan rekayasa sosial berwatak anti politik yang abai terhadap representasi politik rakyat.

Sejalan dengan gagasan tersebut, Harris (2001) mengajukan penjelasan tentang depolitisasi pembangunan guna mengurai paradoks pembangunan. Depolitisasi muncul karena masalah-masalah pembangunan hanya didudukkan sebagai perkara teknokrasi manajerial sehingga kehilangan watak politisnya. Program penanggulangan kemiskinan misalnya, lebih dibaca sebagai problem lemahnya kapasitas teknikal, kurangnya modal, serta karut marutnya manajemen kelembagaan kelompok warga miskin. Fenomena kemiskinan tidak dibaca sebagai ketimpangan akses terhadap kekuasaan/kebijakan dan sumberdaya publik. Ini artinya kebijakan yang demokratis dalam arti kontrol publik terhadap sumber daya dan urusan publik yang bersifat kontestatif dan konfliktual diabaikan. Dalam konteks tersebut, demokrasi dan politik lebih dipahami sebagai prasyarat dasar bagi pertumbuhan ekonomi dan kesejahteraan liberal (Abrahamsen 2000).

Studi kontemporer tentang politik pembangunan di Indonesia, setidaknya terefleksikan dalam proyek kajian Power, Welfare, dan Democracy (PWD) oleh Departemen Politik dan Pemerintahan Universitas Gadjah Mada bekerja sama 
dengan University of Oslo. Kajian tersebut berangkat dari kerisauan proses demokratisasi di Indonesia yang tak kunjung menghantarkan kesejahteraan. Istilah "Kekuasaan" dan "Kesejahteraan" setidaknya menunjukkan keprihatinan awal tentang proses demokratisasi di Indonesia paska reformasi (Santoso dkk 2010 dalam Hiariej dan Stokke 2018). Kajian-kajian tersebut menegaskan dua hal yang sangat krusial. Pertama, diabaikannya isu kekuasaan dalam demokratisasi yang memunculkan arus utama demokrasi elektoral dalam kajian-kajian demokrasi di Indonesia. Elektoralisme menjebak makna demokrasi dalam formalisme - sebatas metode dan prosedur memilih pemimpin. Sehingga Proyek PWD membawa kembali isu relasi hubungan kekuasaan antar aktor, kelompok, kelas dan negara sebagai kunci demokratisasi di Indonesia. Kedua, proses demokratisasi juga mengisolasi diri dari problem kesejahteraan dalam praktik kehidupan keseharian rakyat, seperti persoalan pendidikan, kesehatan, pangan, dan transportasi publik. Pengabaian isu kesejahteraan secara bersamaan terjadi dengan absennya perubahan terhadap hubungan kekuasaan dalam proses transisi demokrasi (Hiariej dan Stokke 2018).

Alhasil, proses demokrasi justru menghasilkan rezim oligarkis (lihat Winter 2014; Hadiz dan Robison 2013). Hadiz dan Robison (2013) melakukan studi yang menggarisbawahi bahwa elit predatorial lama berbasis partai-partai politik menguasai panggung politik. Mereka melakukan reorganisasi kekuasaan mengikuti logika politik kartel, dan ini menjadi basis bagi munculnya oligarki dan plutokrasi. Sejalan dengan pandangan tersebut, Winters (2014) menyatakan bahwa Neo-Orde Baru adalah kaum oligarki yang tak ikut lenyap bersama tumbangnya Orde Baru. Demokratisasi pasca Orde Baru membuat para oligarki bersaing melalui mekanisme kompetisi elektoral. Ringkasnya, Winters ingin menegaskan bahwa oligarki dan demokrasi saling menunggangi. Studi lain yang dilakukan Hee-Yeon Cho (2008) melihat bahwa "demokrasi oligarkis" Indonesia berangsur-angsur berubah menjadi "oligarki demokratis." Inilah sejenis oligarki yang ingin mempertahankan kekayaan - sekaligus merebut kekuasaan - melalui kompetisi elektoral yang berwatak elitis.

Pendekatan struktural berupaya meneropong secara makroskopis terhadap politik pembangunan dengan meletakkan keterkaitan absennya isu hubungan kekuasaan dengan tema kesejahteraan yang bekerja dalam ranah demokratisasi. Dengan demikian, penjelasan tentang paradoks pembangunan dijelaskan melalui fenomena demokratisasi dalam jebakan formalisme yang tidak mengubah ketimpangan hubungan kekuasaan. Dampak dari kondisi ketimpangan tersebut membatasi akses rakyat terhadap kebijakan dan sumber daya publik.

Artikel ini bergerak dalam nalar yang berbeda dengan perspektif struktural. Kajian ini menawarkan konsep governmentality (kepengaturan) yang berada dalam nalar post-strukturalis dalam mengupas paradoks pembangunan. Dengan lensa mikroskopis, perspektif yang ditawarkan dalam penelitian ini justru hendak mencari penjelasan ke dalam ranah mode pembangunan yang bekerja. Meski demikian kajian ini tidak menolak argumen utama dari kajian terdahulu, bahwa kegagalan pembangunan yang berbuah paradoksal sebagai uninteded consequences berangkat dari mode pembangunan yang menghasilkan depolitisasi pembangunan. 
Depolitisasi dilakukan dengan menyingkirkan rakyat dari sirkuit kebijakan sekaligus menggiring mereka sibuk dalam dunia sosial dan ekonomi. Di sisi lain pembangunan dirancang canggih oleh teknokrat dan dijalankan oleh birokrat untuk ekspansi kekuasaan birokrasi negara. Ringkasnya, studi ini justru hendak memperdalam argumen-argumen yang ditampilkan perspektif struktural dengan mencoba menenerobos lebih dalam secara mikroskopis melalui pengkajian jenis kekuasaan yang bekerja dalam rezim pengetahuan tentang pembangunan sekaligus menguji keberlakuan konsep ini dalam mengupas paradoks pembangunan.

\section{Governmentality dan Politik Pembangunan}

Konsep governmentality diperkenalkan oleh Michel Foucault. Governmentality bertolak dari pandangan Foucault tentang tautan kekuasaan dan pengetahuan. Bagi Foucault kekuasaan tidak dipahami sebagai kepemilikan sesuatu untuk mencapai tujuan; tidak pula dipahami secara negatif (koersif) namun produktif; ia ada dimana-mana (omnipresent) dan tidak terpusat; serta mengalir dinormalisasikan dalam praktik pendisiplinan. Pendisiplinan merupakan jenis kekuasaan yang berlangsung terhadap tubuh individu melalui normalisasi. Beroperasinya jenis kekuasaan ini melalui legitimasi oleh rezim pengetahuan tertentu. Normalisasi juga bekerja dalam spektrum lebih luas, yakni terhadap tubuh sosial (populasi/masyarakat) yang dikenal dengan governmentality (Burchell, Gordon, dan Miller 1991).

Governmentality secara sederhana dapat dipahami sebagai kehendak untuk mengatur. Namun demikian tujuan governmentality berbeda dengan pendisiplinan. Jika pendisiplinan bertujuan memperbaiki perilaku melalui normalisasi, maka governmentality bertujuan memastikan peningkatan kesejahteraan banyak orang. Governmentality adalah jenis kekuasaan yang harus dibangun di atas kemampuan menjalankan mandat mensejahterakan orang banyak (Foucault 1991). Dengan demikan, governmentality dipahami sebagai jenis kekuasaan berupa kehendak untuk mengatur demi memperbaiki kehidupan masyarakat, yang oleh Li (2012) disebut sebagai kehendak untuk memperbaiki.

Selanjutnya Li (2012) melihat praktik governmentality bekerja melalui apa yang disebutnya sebagai problematisasi dan teknikalisasi masalah yang merujuk pada praktik identifikasi atas berbagai situasi yang perlu diperbaiki serta mendefinisikan masalah sebagai perihal teknikal yang memuat resep/formulasi sebagai solusinya. Teknikalisasi masalah ini melahirkan demarkasi antara mereka yang dianggap memiliki kepakaran untuk mendiagnosa kekurangan orang lain dengan mereka yang menjadi obyek yang diatur. Gagasan Li, sejalan pula dengan gagasan Ferguson tentang "mesin anti politik" yang melihat kekuasaan para ahli yang cenderung meminggirkan kuasa rakyat. Di sisi lain, pembangunan dirancang canggih oleh teknokrat dan dijalankan oleh birokrat untuk ekspansi kekuasaan birokrasi negara (Eko 2015).

Perbedaan mendasar dengan perspektif struktural, konsep governmentality tidak melihat hal itu bekerja untuk melayani kepentingan penguasa yang bersifat konspiratif (lihat pula Escobar 1995). Namun melihat, bahwa para ahli yang diberi 
tanggung jawab mengurus hajat hidup masyarakat tidak bisa mendukung kepentingan kelompok tertentu, mereka harus menyeimbangkan semua jenis hubungan antara "manusia dengan segala sumber penghidupannya" (Li 2012). Menurut Foucault (1991), governmentality bukanlah diabdikan untuk tujuan dogmatis (melayani penguasa), namun hasil akhir spesifik. Di mana hasil akhir sangat beragam sehingga membuahkan intervensi yang beragam yang tidak sejalan satu dengan lainnya, bersitegang, bahkan benar-benar kontradiktif (Li 2012; lihat pula Flynn 1994; Stoler 2002).

Penelitian ini berada dalam aras kerangka pemikiran tersebut. Dengan konsep govermentality, hendak mengurai situasi paradoksal yang lahir karena kehendak untuk memperbaiki namun berbuah konsekuensi yang tidak diniatkan. Perhatian terutama diarahkan untuk memeriksa kembali rezim pengetahuan tentang pembangunan yang diuji baik secara diskursif maupun pada ranah praktik sosial. Dalam konteks itu, kajian ini akan memusatkan bagaimana persoalan substantif pembangunan direduksi menjadi perkara teknis dan bagaimana kajian kritis mengalami titik pembalikan yang diserap balik ke dalam wilayah kepakaran menjadi program kepengaturan yang bersifat tertutup (Rose 1999).

\section{Lanskap Sosial Ekonomi Desa Mangunan}

Desa Mangunan terletak di wilayah Kecamatan Dlingo, Kabupaten Bantul. Dengan luas wilayah 9,52 $\mathrm{Km}^{2}$ yang terdiri dari 6 pedukuhan, lanskap Desa Mangunan sebagian besar yaitu $70 \%$ terdiri dari kawasan perbukitan dan hanya sekitar $30 \%$ berupa dataran. Tidak mengherankan jika sebagian besar lahan berupa hutan dan tegalan dan hanya menyisakan 130,22 Ha tanah sawah pertanian. Bandingkan dengan Lahan Bukan Sawah sebesar 409,62 Ha dan Lahan Non Pertanian 884, 02 Ha.(BPS Dlingo Dalam Angka 2019). Jenis tanah pertaniannya beragam, namun didominasi oleh tanah margalit dan sulit air. Oleh karena itu, musim tanam hanya berlangsung dua kali dalam setahun. Setiap musim kemarau tidak dapat ditanamami padi, dan hanya bertanam palawija.

Terkait dengan kependudukan di Desa Mangunan, Badan Pusat Statistik Kabupaten Gunungkidul mencatat hingga tahun 2017, Desa Mangunan memiliki jumlah penduduk sebanyak 4.763 jiwa, yang terdiri dari 2.364 laki-laki dan 2.399 perempuan (Profil Desa Mangunan 2018). Dengan menempati wilayah seluas 9,52 $\mathrm{km}^{2}$ dan jumlah penduduk 4.763 jiwa, Desa Mangunan memiliki kepadatan penduduk mencapai 500,12 jiwa $/ \mathrm{km}^{2}$. Penduduk terbanyak berada di Pedukuhan Sukorame dengan persentase $22,02 \%$ dari total jumlah penduduk desa dan jumlah paling sedikit berada di Pedukuhan Lemahbang $(13,79 \%$ dari total jumlah penduduk desa). Sedangkan berdasarkan rasio jenis kelamin (sex ratio), jumlah penduduk desa terbanyak adalah penduduk perempuan dibandingkan jumlah penduduk laki-laki dengan angka sex ratio dibawah angka 100.

Sedangkan menurut kelompok umur, Desa Mangunan didominasi oleh penduduk usia produktif pada tahun 2017 (Lihat Tabel 1, RPJM Desa Mangunan 2018-2024). Penduduk usia angkatan kerja (15-64 tahun) sebesar 68,25\% dari total penduduk desa (3.179 jiwa) sedangkan jumlah penduduk usia non produktif (0-14 tahun dan >65 tahun) sebesar 31,75\% (1.479 jiwa). Dengan rasio 
ketergantungan (dependency ratio) sebesar 46,52 yang menunjukkan rata-rata 100 penduduk usia produktif di Desa Mangunan masih harus menanggung kurang lebih 47 penduduk usia non produktif.

Tabel 1. Jumlah Penduduk Menurut Kelompok Umur di Desa Mangunan Tahun 2017

\begin{tabular}{|c|c|r|r|r|}
\hline \multirow{2}{*}{ No. } & \multirow{2}{*}{$\begin{array}{c}\text { Kelompok } \\
\text { Umur }\end{array}$} & \multicolumn{2}{|c|}{$\begin{array}{c}\text { Jumlah Penduduk } \\
\text { (jiwa) }\end{array}$} & \multirow{2}{*}{$\begin{array}{c}\text { Jumlah } \\
\text { (jiwa) }\end{array}$} \\
\cline { 3 - 4 } & & $\begin{array}{c}\text { Laki- } \\
\text { Laki }\end{array}$ & Perempuan & \\
\hline 1 & $0-14$ & 458 & 447 & $\mathbf{9 0 5}$ \\
\hline 2 & $15-64$ & 1.590 & 1.589 & $\mathbf{3 . 1 7 9}$ \\
\hline 3 & $>65$ & 273 & 301 & $\mathbf{5 7 4}$ \\
\hline
\end{tabular}

Komposisi penduduk menurut tingkat pendidikan dapat dilihat dari persentase penduduk usia 5 tahun ke atas menurut status pendidikan yang berpengaruh pada kualitas sumber daya manusia. Akses mendapatkan pendidikan jauh lebih mudah karena jarak tempat pendidikan dari jenjang paling rendah yaitu Taman Kanak-Kanak (TK) hingga jenjang pendidikan Sekolah Menengah Atas (SMA) dekat dengan pemukiman warga. Meski akes ke layanan pendidikan cukup terbuka di Desa Mangunan, namun persoalan yang dihadapi adalah masih banyaknya warga dengan tingkat pendidikan rendah. Data penduduk menurut tingkat pendidikan dapat dilihat dalam Tabel 2 (RPJM Desa Mangunan 2018-2024). Tabel tersebut menunjukkan bahwa sebagian besar penduduk Desa Mangunan sebesar 30,91\% dari total jumlah penduduk desa memiliki pendidikan terakhir yaitu tamat SD, diurutan kedua adalah penduduk yang belum sekolah yaitu penduduk yang berumur 0-5 tahun $(21,66 \%)$.

Tabel 2. Jumlah Penduduk Menurut Tingkat Pendidikan Desa Mangunan Tahun 2017

\begin{tabular}{|c|l|r|}
\hline No. & Jenjang Pendidikan & Jumlah \\
\hline 1 & Belum Sekolah & 1.009 \\
\hline 2 & Belum Tamat SD & 341 \\
\hline 3 & Tamat SD & 1.440 \\
\hline 4 & Tamat SMP & 980 \\
\hline 5 & Tamat SMA & 757 \\
\hline 6 & D1/D2 & 25 \\
\hline 7 & D3 & 42 \\
\hline 8 & S1 & 61 \\
\hline 9 & S2 & 3 \\
\hline & Total & $\mathbf{4 . 6 5 8}$ \\
\hline
\end{tabular}

Perekonomian Desa Mangunan sebagian besar ditopang oleh aktivitas pertanian, disusul sektor pariwisata yang tercermin dari mata pencaharian warga. 
Sebagian besar penduduk Desa Mangunan memiliki mata pencaharian di sektor pertanian atau sebagai petani $(21,64 \%$ dari total jumlah penduduk desa). Hal ini menunjukkan bahwa sektor pertanian masih menjadi sektor utama dan memiliki peranan penting dalam perekonomian masyarakat. Jumlah penduduk menurut mata pencaharian dapat dilihat pada tabel 3 (Lihat Tabel 2, RPJM Desa Mangunan 2018-2024).

Tabel 3. Jumlah Penduduk Menurut Mata Pencaharian Desa Mangunan Tahun 2017

\begin{tabular}{|c|l|r|}
\hline No. & \multicolumn{1}{|c|}{ Mata Pencaharian } & $\begin{array}{c}\text { Jumlah Penduduk } \\
\text { (jiwa) }\end{array}$ \\
\hline 1 & Belum/Tidak Bekerja & 655 \\
\hline 2 & Mengurus Rumah Tangga & 187 \\
\hline 3 & Pelajar/Mahasiswa & 665 \\
\hline 4 & Pensiunan & 19 \\
\hline 5 & PNS & 63 \\
\hline 6 & TNI/Polri & 4 \\
\hline 7 & Pedagang & 72 \\
\hline 8 & Petani/Pekebun & 1.008 \\
\hline 9 & Peternak/Nelayan & 4 \\
\hline 10 & Karyawan & 128 \\
\hline 11 & Buruh & 829 \\
\hline 12 & Tukang & 30 \\
\hline 13 & Guru & 15 \\
\hline 14 & Bidan/Perawat & 6 \\
\hline 15 & Perangkat Desa & 19 \\
\hline 16 & Wiraswasta & 686 \\
\hline 17 & Lainnya & 268 \\
\hline & Total & $\mathbf{4 . 6 5 8}$ \\
\hline
\end{tabular}

Sumber: mangunan.bantulkab.go.id (diakses 2019)

Meskipun petani/pekebun mendominasi mata pencaharian di Desa Mangunan, tetapi jenis mata pencaharian yang ada di desa ini juga cukup beragam. Selain petani/pekebun, jenis mata pencaharian yang cukup banyak di desa ini adalah buruh, baik buruh harian lepas, buruh tani/kebun, dan buruh nelayan/perikanan. Ada juga wiraswasta, pelajar/mahasiswa juga cukup banyak jumlahnya. Selain sektor pertanian, dalam 5 tahun terakhir tumbuh pula sektor wisata Desa Mangunan. Sektor pariwisata Desa Mangunan memang sangat berkembang pesat yang ditandai dengan banyaknya obyek wisata dan kunjungan wisatawan domestik maupun mancanegara. Dalam kurun 5 tahun terakhir kunjungan wisatawan domestik maupun asing telah mencapai rata-rata 2 juta pengunjung setiap tahunnya. Daya tarik wisata di Mangunan adalah wisata alam seperti hutan pinus, kebun buah dan wisata budaya.

Hal ini membawa dampak bagi terbukanya lapangan kerja baru dan munculnya usaha-usaha baru seperti warga yang terserap dalam pengelola wisata, pemandu wisata, home stay, pemilik warung makan/resto, jeep wisata, pedagang 
cinderamata, serta usaha-usaha pendukung wisata lainnya. Bahkan dampak konkrit dari perkembangan sektor ini telah mampu memberikan kontribusi pendapatan asli bukan hanya kepada Desa dalam bentuk PADes namun juga untuk daerah dalam bentuk PAD. Meski sektor wisata berhasil membuka kesempatan kerja baru, jumlah penduduk yang tidak/belum bekerja (pengangguran) di desa ini tidak sedikit yaitu sekitar 14,06\% dari total penduduk desa. Permasalahan berkaitan yang sering muncul dengan mata pencaharian penduduk adalah lapangan pekerjaan yang masih kurang tersedia dan memadai sesuai dengan perkembangan penduduk.

\section{Metode}

Kajian ini merupakan penelitian kualitatif dengan menggunakan strategi studi kasus sebagai metode kajiannya. Studi kasus dipilih dalam kajian ini karena metode ini diyakini unggul dalam mencapai tujuan kajian kualitatif yakni kekhususan dalam makna kedalaman dan kompleksitas dari suatu fenomena sosial. Studi kasus sendiri merupakan pengujian secara rinci terhadap sebuah latar, subjek atau peristiwa tertentu (Bogdan dan Bikien 1982). Pendeknya, studi kasus adalah suatu studi tentang kekhususan sekaligus kompleksitas suatu kasus, untuk membangun pemahaman subyek dalam kondisi alamiah yang menggunakan sejumlah teknik pengumpulan data (Stake 2005; Yin 1996).

Karakteristik sudi kasus tersebut didudukkan dalam konteks kekhususan dan kompleksitas tindakan sosial yang diteliti, sebagaimana disampaikan Stake (2005) bahwa ranah studi kasus adalah partikularisasi bukan universal atau generalisasi. Namun bukan berarti generalisasi tidak dimungkinan dalam studi jenis ini. Generalisasi yang dimaksud dalam studi ini berupa generalisasi analitis (teoritis) yang diorientasikan untuk pengembangan teori sebagaimana dinyatakan Yin (1996). Kecenderungan generaliasasi analitis merupakan salah satu jenis studi kasus yakni studi kasus instrumental dan kolektif (Stake 2005). Kajian ini menempatkan jenis studi kasus instrumental yang diorientasikan untuk memperkaya khazanah teoritik. Studi kasus intrumental dipilih manakala kasus yang dikaji dapat dipergunakan menyempurnakan teori yang eksis atau membangun teori baru.

Data kajian ini terdiri dari data primer dan data sekunder. Data sekunder dikumpulkan dengan teknik dokumentasi dengan menggunakan sumber berupa dokumen-dokumen tertulis maupun audio visual yang digunakan untuk mendukung dan memperkuat pencatatan selama berlangsungnya penelitian. Dokumen tertulis yang dimaksud berupa data sosial, ekonomi, dan budaya di lokasi kajian seperti berupa data profil dan demografi desa; regulasi desa dan kabupaten terkait pembangunan; data dokumen perencanaan pembangunan dan pelaporan capaian pembangunan desa; data penelitian terdahulu yang relevan di lokasi kajian, maupun data media. Dokumentasi data sekunder dilakukan untuk memudahkan saat nantinya digunakan untuk memperkuat data-data primer. Dokumentasi data sekunder memungkinkan peneliti mendapatkan informasi pada hal-hal yang terjadi pada masa lampau maupun data olahan tertentu, seperti data 
statistik, yang dapat memberikan gambaran obyek penelitian. Data primer dikoleksi sebagai data pokok yang berbentuk catatan lapangan yang didapat melalui wawancara dan pengamatan langsung. Wawancara dilakukan kepada sejumlah informan kunci yang terdiri dari pemerintah desa, BPD, tokoh masyarakat, pelaku usaha, dan warga.

\section{Hasil dan Pembahasan}

\section{Tata Kelola Desa Wisata dan Persoalan Kemiskinan}

Sebagai salah satu destinasi wisata di Yogyakarta, Desa Mangunan dikenal memiliki banyak spot wisata. Rintisan sebagai destinasi wisata dimulai sejak dibukanya Kebun Buah Mangunan pada tahun 2003 lalu. Kebun Buah Mangunan, wisata buatan ini dipenuhi dengan kebun buah dan beberapa spot bersantai. Namun saat itu, Desa Mangunan belum berkembang sebagai Desa Wisata. Kebun Buah Mangunan yang dikelola Pemerintah Daerah Bantul saat itu belum mampu menjadi daya dorong dan memeberikan multiflier effect bagi pengembangan desa wisata.

Dalam perkembangannya, terdapat obyek wisata Hutan Wisata Pinus yang mulai ramai dikunjungi wisatawan dalam tahun 2014. Hutan wisata pinus yang berada dalam penguasaan Dinas Kehutanan dan Perkebunan DIY ini mampu menjadi daya tarik bagi wisatawan baik dalam dan luar negeri sekaligus menjadi pemantik dibukanya spot-spot wisata di Desa Mangunan. Sepanjang 2015 hingga 2018 setidaknya terdapat 10 destinasi wisata baru di buka di Desa Mangunan. Beberapa objek wisata di atas terkenal karena beberapa titik-titiknya yang menyajikan pemandangan alam yang indah sehingga cukup terkenal di kalangan anak muda sebagai spot foto yang "instagramable". Beberapa objek wisata juga diperindah oleh warga dengan menambahkan titik atau spot yang bisa digunakan untuk tempat berfoto. Hingga Tahun 2019 di Desa Mangunan terdapat 11 obyek wisata alam sebagaimana dijelaskan dalam tabel 4 berikut ini.

Tabel 4. Daftar Wisata Alam di Desa Mangunan

\begin{tabular}{|c|l|l|}
\hline No. & Nama Wisata & Lokasi \\
\hline 1 & Watu Goyang & Dukuh Cempluk \\
\hline 2 & Watu Lawang & Dukuh Mangunan \\
\hline 3 & Jurang Tembelan & Dukuh Kanigoro \\
\hline 4 & Rumah Seribu Batu & Dukuh Sukorame \\
\hline 5 & Jelajah Sawah Pertanian Bowongan & Dukuh Sukorame \\
\hline 6 & Hutan Pinus Sari & Dukuh Sukorame \\
\hline 7 & Goa Gajah & Dukuh Lemahbang \\
\hline 8 & Tebing Watu Mabur & Dukuh Lemahbang \\
\hline 9 & Bukit Mojo & Dukuh Kediwung \\
\hline 10 & Bukit Panguk & Dukuh Kediwung \\
\hline 11 & Telaga Giri & Dukuh Kediwung \\
\hline
\end{tabular}


Selain wisata alam, Desa Mangunan juga menyuguhkan wisata buatan yakni Kebun Buah Mangunan dan Desa Wisata Kaki Langit yang berada di Pedukuhan Mangunan. Berbeda dengan Kebun Buah Mangunan, Desa Wisata Kaki Langit yang berada tidak jauh dari kebun buah merupakan objek wisata religi, sejarah, budaya, bahkan kuliner yang dipadukan keindahan lingkungan khas pedesaan. Daya tarik wisata di Desa Wisata Kaki Langit ini memadukan kekayaan seperti kesenian lokal maupun tradisi adat istiadat masyarakat setempat. Desa Mangunan sendiri masuk dalam kategori desa rintisan budaya dengan potensi wisata budaya seperti upacara adat, kesenian daerah, tempat bersejarah, rumah adat, benda kuno, dan kerajinan serta kuliner tradisional.

Perkembangan wisata di Mangunan tentu memberikan multiflier effect bagi warga sekitar dengan terbukanya kesempatan ekonomi dan peluang kerja baru. Banyak warga yang terjun sebagai pengelola wisata, membuka warung/sektor kuliner, menjadi pemandu wisata, membuka jasa home stay, menjajakan cinderamata, menawarkan paket jeep wisata, dan usaha-usaha lain yang relevan dengan industri wisata di Mangunan.

Tata kelola berbagai obyek wisata di Desa Mangunan memunculkan model rezim pengelolaan yang beragam berdasarkan penguasaan aset di obyek wisata tersebut. Pertama, obyek wisata yang dikelola oleh Pemerintah Kabupaten Bantul yakni Kebun Buah Mangunan. Obyek wisata ini menempati Tanah Desa yang disewa oleh Pemerintah Kabupaten Bantul. Pengelolaan obyek ini dibawah Dinas Pertanian Kabupaten Bantul. Pengaturan selanjutnya mengikuti Peraturan Daerah Kabupaten Bantul. Kedua, obyek wisata yang dikelola oleh Koperasi Noto Wono yakni Pinus Asri, Rumah Seribu Batu, Bukit Mojo dan Bukit Panguk. Keempat obyek tersebut menempati kawasan hutan di bawah kewenangan Dinas Kehutanan dan Perkebunan Provinsi DIY. Pengelolaan wisata di obyek tersebut dikelola Koperasi Noto Wono yang dibentuk oleh kelompok warga sekitar hutan di Kecamatan Dlingo. Penguasaan obyek wisata oleh Koperasi Noto Wono ini total terdapat 10 Obyek wisata di 4 Desa yang membentang dari Hutan Wisata Pengger (di Desa Munthuk) hingga Bukit Mojo (di Desa Mangunan).

Ketiga, obyek wisata yang menempati Tanah Desa seperti Watu Goyang, Watu Mabur, Watu Mabur, dan Sendang Giri. Pengelolaan spot-spot tersebut biasanya dikelola oleh komunitas warga padukuhan di bawah kendali Kelompok Sadar Wisata (Pokdarwis). Obyek wisata ini umumnya menempati tanah desa yang didayagunakan oleh warga setempat yang mana hasilnya dibagi untuk pengelola dan disetor ke Desa sebagai pungutan untuk sumbangan Pendapatan Asli Desa. Keempat, obyek wisata yang menempati tanah-tanah privat seperti jurang tembelan. Pengelolaan spot tersebut oleh pemilik lahan bersama dengan komunitas warga setempat.

Sejalan dengan paparan tersebut, temuan dalam kajian ini mendapati masih banyak keluarga miskin di Desa Mangunan. Hingga tahun 2019, terdapat 410 Kepala Keluarga peserta Program Keluarga Harapan di Desa Mangunan. Sedangkan Basis Data Terpadu (BDT) yang diterbitkan Tim Nasional Percepatan Penanggulangan Kemiskinan merilis data 3 desil terbawah warga Mangunan pada 
tahun 2019 sebanyak 809 KK dari total 1526 KK. Jumlah tersebut lebih dari 50 \% KK di Mangunan termasuk dalam kategori kurang sejahtera.

Tabel 5. Jumlah KK dalam Basis Data Terpadu Kemiskinan Tahun 2019

\begin{tabular}{|l|c|}
\hline \multicolumn{1}{|c|}{ Padukuhan } & Jumlah KK \\
\hline Cempluk & 142 \\
\hline Mangunan & 78 \\
\hline Sukorame & 197 \\
\hline Lemahbang & 136 \\
\hline Kanigoro & 136 \\
\hline Kediwung & 120 \\
\hline Total & 809 \\
\hline
\end{tabular}

Sumber: BDT desa Mangunan, Data diolah

Jumlah tersebut bahkan bertambah pada tahun 2020 seiring demgan Pandemi Covid-19. Pada tahun 2020 diperkirakan lebih dari 200 KK masuk dalam tambahan data BDT. Mereka yang masuk dalam daftar tersebut adalah keluarga yang rentan miskin manakala terdapat goncangan, seperti situasi Pandemi hari ini. Apalagi industri wisata yang menjadi andalan Desa Mangunan adalah salah satu sektor yang paling awal dihantam krisis dan menjadi sektor yang paling terdampak. Banyak dari mereka yang menggantungkan dari berputarnya roda industri wisata, di mana mereka menjadi bagian dari mata rantai industri wisata akhirnya menganggur. Pada akhirnya mereka kembali terperosok di bawah garis kemiskinan dan melengkapi barisan yang sebelumnya telah masuk dalam jajaran warga miskin.

Profil keluarga miskin sebagian adalah keluarga pasangan lanjut usia yang hidup sebatang kara tanpa keluarga, janda dengan sejumlah tanggungan (anak), keluarga muda dengan tingkat pendidikan rendah dan tanpa kerampilan. Mereka yang masih di bawah garis kemiskinan umumnya gagal mengakses berbagai peluang ekonomi maupun kesempatan kerja di sektor wisata. Ataupun jika mereka masuk ke dalam industri wisata, mereka menempati lapis terbawah dalam struktur piramida wisata. Umumnya mereka hanya sebagai buruh di warung makan, pekerja kasar di obyek wisata, penjaja asongan, dan sejenisnya. Gula-gula wisata yang mereka nikmati hanya sebatas meringankan beban kehidupan dalam deraan kemiskinan, namun belum mampu mengentaskan mereka dari kemiskinan. Sebagaimana dinyatakan dalam dokumen RPJM Desa Mangunan salah satu masalah dalam industri wisata adalah "pendapatan kegiatan parwisata belum berdampak merata pada peningkatan kesejahteraan semua warga".

\section{Standar Industri Pariwisata sebagai Rezim Pengetahuan yang Dominan}

Wisata telah menjadi denyut nadi baru yang menggerakkan energi aktivitas warga di Mangunan dalam lima tahun terakhir ini. Jutaan pengunjung yang terus mengalir deras ke berbagai obyek wisata di Mangunan. Di setiap akhir pekan, jalur menuju berbagai obyek wisata di Mangunan mengalami kemacetan, suatu 
pemandangan yang tidak terbayangkan pada tahun-tahun sebelumnya. Jalan-jalan menuju berbagai obyek wisata pun dalam kurun tiga tahun terakhir ini begitu mulus, nyaris tak ditemui jalan-jalan berlubang. Kondisi tersebut juga ditemui di sudut-sudut desa dengan akses jalan yang memudahkan wisatawan menelusur hingga ke pelosok kampung. Berbagai guyuran proyek infrastruktur berupa jalan dan pembangunan fasilitas fisik wisata yang begitu masif telah mengubah wajah Mangunan begitu menawan.

Dalam kurun waktu lima tahun terakhir, muncul puluhan spot-spot baru obyek wisata, puluhan home stay, puluhan warung makan hingga resto. Demikian pula usaha-usaha baru di sektor wisata juga muncul seperti toko oleh-oleh, penyedia jasa persewaan kendaraan wisata dan usaha pedukung hospitality lainnya seperti laundry, mini mart, hingga stasiun pompa bensin mini. Tak kalah pentingnya, profesi seperti pemandu wisata dan pengelola obyek wisata menjadi prestis baru bagi warga setempat. Kesemuanya itu telah membuka peluang dan kesempatan ekonomi baru bagi warga. Wisata pada akhinya membuka harapan baru bagi warga untuk memperbaiki kualitas kehidupan dan kesejahteraan warga pada umumnya. Ringkasnya, kata "wisata" telah menjadi diskursus utama bagi warga Mangunan dalam lima tahun terakhir ini.

Tak kalah marak dengan masuk jutaan wisatawan, wisata telah menjadi praktik diskursif baru yang menyesaki ruang-ruang publik warga Mangunan. Sejalan dengan hal itu, juga diiringi dengan masuknnya pengetahuan baru tentang wisata. Para pelaku industri wisata di Mangunan pun mendapat asupan pengetahuan tentang bagaimana mengelola industri wisata. Jenis pengetahuan ini mendudukkan para pelaku wisata di Mangunan adalah pihak yang belum cakap mengelola bisnis wisata secara profesional, dan yang melihat problem pariwisata di Mangunan adalah perkara teknis berupa rendahnya kualitas Sumber Daya Manusia pengelola wisata. Mereka diikutsertakan dalam beragam program pelatihan manajemen teknis pariwisata seperti pelatihan kepemanduan, pengelolaan home stay, pelatihan mengemas produk makanan, pelatihan promosi dan pemasaran, pengelolaan warung makan, dan sebagaianya.

Kontribusi beragam program pelatihan yang acapkali dikemas dalam bahasa "pemberderdayaan" warga tersebut memang telah mendorong perkembangan industri wisata di Mangunan. Kesadaran hospitality karena suntikan pengetahuan telah membuat para pelaku wisata setempat bergegas mengejar berbagai standar yang berlaku di industri pariwisata. Salah seorang pengelola home stay misalnya, menuturkan dalam berbagai pelatihan mereka acap kali mendapat materi tentang standar kamar yang mengikuti standar hotel. Mereka mengakui standar tersebut memiliki konsekuensi pembiayaan yang tidak sedikit. Tidak mudah bagi mereka untuk memenuhi standar tersebut. Sebagai jalan tengah, mereka menyatakan berupaya mendekati standar tersebut, meskipun tidak cocok untuk konsep wisata yang mereka tawarkan pada pengunjung.

Dalam konteks tersebut, pengetahuan yang didapatkan para pelaku industri wisata memiliki dua wajah. Bagi mereka yang dapat "mengamalkan" upaya-upaya pemenuhan standar telah menghantar para pelaku wisata di Mangunan mendapat limpahan kunjungan wisatawan. Meski demikian mereka harus menambah modal 
untuk dapat mencapai standar agar dapat masuk jejaring pemasaran yang digerakkan biro wisata di kota. Sedangkan bagi mereka yang demikian terbatas, berbagai pelatihan tersebut tidak banyak berguna, dan mereka memasang berbagai strategi yang dapat memberikan nilai tambah bagi keunggulan usaha mereka. Misalnya, mereka lebih mengedepankan aspek-aspek intangible seperti menjual aspek keramahtamahan yang dibungkus dengan budaya setempat sebagai keunggulan kompetitif dengan pelaku usaha lainnya.

Berbagai standar tersebut pada saat yang sama telah mengeksklusi sebagian warga yang mencoba beragam kesempatan ekonomi baru tersebut. Standarstandar dalam industri wisata hanya dapat dipenuhi kelompok-elompok elit desa dan sedikit warga yang memiliki kontak jejaring dengan Pemerintah atau pelaku industri kreatif di kota. Bahkan banyak warga miskin, gagal sejak awal memasuki standar industri wisata di Mangunan. Sebagian warga miskin yang berhasil yang masuk dalam struktur industri wisata pun menghuni lapis-lapis terbawah dalam struktur industri wisata di Mangunan. Umumnya mereka hanya bekerja sebagai pekerja kasar.

Senyatanya beragam program pelatihan tersebut begitu gencar dilakukan oleh banyak pihak. Program pelatihan dan pendampingan yang memuat rezim pengetahuan tersendiri terutama dipasok oleh agen-agen pemerintah, misi tanggung jawab sosial perusahaan, hingga lembaga donor melalui agen-agen lokal mereka. Badan pemerintah seperti dinas pariwisata baik di tingkat kabupaten dan provinsi misalnya, menjadi pihak yang paling sering menggelontorkan berbagai program-program tersebut. Setiap tahun mereka merencanakan dan menganggarkan program yang sama bagi pelaku industri wisata di Mangunan. Program-program pelatihan serupa juga digelontorkan oleh dinas-dinas lain dengan nomenklatur yang berbeda.

Tak mau ketinggalan dengan badan pemerintah, korporasi juga masuk melalui skema tanggung jawab sosial perusahaan atau corporate social responsibility (CSR). Sedikit berbeda dengan badan pemerintah, skema CSR biasanya berupa bantuan fasilitas fisik untuk obyek wisata yang dikombinasikan dengan programprogram pelatihan serupa sekadarnya. CSR perusahaan lebih menyukai pemberian bantuan fisik yang sekaligus dapat dimanfaatkan secara langsung sebagai media branding. Sementara itu, program-program pelatihan hanya didesain sesuai dengan kepentingan pasar korporasi di wilayah tersebut. Misalnya, ketika korporasi tersebut adalah lembaga keuangan, mereka berkepentingan mendesain pelatihan untuk memuluskan pemasaran produk-produk jasa keuangan mereka pada pelaku usaha wisata di Mangunan.

Demikian pula dengan lembaga-lembaga donor, mereka juga bertindak sebagai agen pengetahuan. Berbeda dengan badan pemerintah atau CSR, melalui agen-agen lokal mereka mendorong pelembagaan konsep seperti sustainable tourism atau community based tourism. Lembaga donor berkepentingan mendorong konsep-konsep tersebut ke dalam praktik tata kelola wisata di Mangunan. Konsep-konsep tersebut sebetulnya tengah mengantisipasi eksternalitas dampak wisata. Sayangnya, operasionalisasi pengetahuan tersebut 
juga terjebak dalam pendekatan teknis seperti pendekatan penghidupan (livelihood) yang naif.

\section{Siasat Desa atas (Data) Kemiskinan}

Pada gilirannya, program-program pengembangan wisata tidak memiliki relasi yang kuat terhadap upaya penanggulangan kemiskinan. Janji peningkatan kesejahteraan melalui pengembangan wisata senyatanya tidak beranjak menekan atau mengentaskan kemiskinan di Mangunan. Justru wisata secara perlahan menciptakan jurang ketimpangan baru diantara warga di Mangunan. Hanya mereka yang memiliki akses terhadap beragam sumber daya saja yang dapat mengembangkan berbagai kesempatan ekonomi yang disediakan wisata. Mereka yang terbatas tetap saja gagal tumbuh mana kala masuk ke dalam struktur industri wisata. Ringkasnya, problem kemiskinan tidak tersentuh dengan memadai melalui pertumbuhan sektor wisata di Mangunan. Paling tinggi, beragam program tersebut hanya meringankan beban si miskin.

Beban warga miskin yang berkurang di Mangunan dengan berkembangnya wisata, senyatanya hanya memindahkan mereka sedikit di atas garis kemiskinan. Posisi demikian menjadikan mereka rentan miskin. Manakala didesak oleh berbagai keperluan mendadak seperti kebutuhan berobat keluarga yang sakit, keperluan membiayai sekolah anak, atau terlilit hutang, langsung menguras tabungan dan aset mereka. Warga dengan status semacam ini bisa saja mendadak turun kelas dan kembali menjadi warga miskin. Di Mangunan, merekalah lapis terbesar.

Mereka yang rentan miskin sesungguhnya menjadi pihak yang paling tidak terlindungi. Warga miskin justru terlindungi dengan beragam program perlindungan sosial seperti Program Keluarga Harapan (PKH), Bantuan Pangan Non Tunai, Jaminan Kesehatan, dan Jaminan Pendidikan. Sedangkan warga rentan miskin tidak mempunyai akses perlindungan sosial seperti ragam subsidi negara untuk warga miskin. Dalam konteks tersebut, Desa menjadi andalan mereka dalam mengakses beragam bantuan publik maupun subsidi negara.

Guna memastikan perlindungan sosial secara memadai, Pemerintah Desa bersiasat atas kondisi tersebut. Hingga tahun 2018 sekitar separuh dari jumlah keseluruhan keluarga di Mangunan masuk dalam Basis Data Terpadu (BDT) Kemiskinan. BDT sendiri merupakan data yang menjadi dasar bagi pemberian program pengentasan kemiskinan terutama untuk warga yang masuk dalam tiga desil terbawah. Jumlah warga tersebut meningkat hingga sekitar 809 KK pada tahun 2019. Pada masa Pandemi diperkirakan 70-75 \% KK di Mangunan masuk dalam BDT.

Untuk masuk dalam daftar BDT, pemerintah desa melakukan survey untuk mengukur kondisi kemiskinan berdasarkan 14 indikator yang ditetapkan. Namun demikian, tidak mudah bagi pemerintah desa untuk memastikan apakah warga layak masuk dalam BDT. Beberapa warga yang masuk dalam indikator BDT, namun sesungguhnya memiliki aset yang cukup besar berupa tanah, ladang, kayu, ternak dan sebagainya. Sementara, banyak pula warga yang tidak memenuhi indikator BDT, namun sesunguhnya posisinya cukup rentan. Ringkasnya, indikator 
yang dikembangkan dalam BDT acapkali tidak sensitif dengan perspesi lokal terhadap kemiskinan.

Peningkatan jumlah warga yang masuk dalam BDT merupakan strategi pemerintah desa untuk memastikan akses warga rentan miskin agar dapat mengakses bantuan-bantuan maupun subsidi negara. Sebab, salah satu syarat memperoleh beragam bantuan, warga harus terdaftar dalam BDT. Strategi tersebut, sekaligus sebagai upaya Pemerintah Desa mengurangi tekanan warga terhadap tekanan kemiskinan yang terus mengancam. Misalnya, warga rentan miskin yang menghadapi problem pembiayaan berobat manakala terdapat anggota keluarga yang sakit. Sementara mereka tidak memiliki jaminan kesehatan, mereka akan mengandalkan rekomendasi desa untuk mengurus keringanan pembiayaan. Demikian pula, apabila terdapat keluarga rentan miskin yang membutuhakan biaya kuliah untuk anak-anak mereka, mereka akan mengurus surat keterangan tidak mampu untuk mengakses beasiswa.

\section{Kesimpulan}

Kendati program pengembangan wisata dibangun atas nama "peningkatan kesejateraan warga" senyatanya program-program tersebut hanya melayani pertumbuhan sektor wisata berbasis standar usaha pariwisata. Hal ini tampak dari rezim pengetahuan yang mendasari keberadaan program-program tersebut. Pengetahuan semacam ini, hanya disiapkan untuk menjalankan misi mendorong pertumbuhan industri wisata ketimbang mengatasi berbagai kemungkinan dampak wisata. Rezim pengetahuan semacam ini hanya mungkin dijalankan oleh para pelaku yang memiliki akses lebih baik terhadap beragam sumber daya untuk memenuhi berbagai standar yang dibangun oleh rezim pengetahuan tersebut. Sementara, warga dengan kapasitas sumber daya terbatas tidak dapat memenuhi berbagai standar tersebut. Rezim pengetahuan semacam ini justru memperlebar ketimpangan antar warga.

Jenis pengetahuan semacam ini juga melihat problem kesejahteraan sebagai perkara teknis ketimbang menempatkannya sebagai problem struktural. Pengetahuan teknis atau yang oleh Li (2012) disebut sebagai teknikalisasi masalah tidak disiapkan untuk memastikan distribusi sumber daya yang lebih adil. Pengetahuan teknis tidak dapat menjangkau problem-problem struktural seperti kemiskinan. Dengan kemasan wacana "peningkatan kesejahteraan", berbagai pengetahuan teknis tersebut terdengar naif hendak menyelesaikan problem struktural seperti kemiskinan. Pertumbuhan sektor wisata justru menciptakan lapis terbesar warga di Mangunan yakni warga rentan miskin. Warga dengan status rentan miskin inilah yang justru yang paling tidak terlindungi dalam berbagai program perlindungan sosial. Posisi mereka terjepit, sewaktu-waktu ancaman jatuh ke jurang kemiskinan mengintai mereka karena mereka tidak cukup punya akses terhadap subsidi negara.

Upaya penanggulangan kemiskinan menjadi program yang terpisah dengan program pengembangan wisata. Penanggulangan kemiskinan menempatkan desa sebagai sasaran berbagai program penanggulangan kemiskinan yang hanya dapat 
diakses oleh warga yang terdaftar dalam BDT. Warga yang masuk dalam daftar BDT acapkali dipersepsikan warga miskin. Karena salah satu instrumen teknis untuk meraih berbagai subsudi negara haruslah masuk dalam BDT, meskipun sesungguhnya bukan warga dalam kategori miskin. Senyatanya angka kemiskinan yang meningkat tajam di Mangunan hadir sebagai siasat pemerintah desa melindungi warga yang rentan miskin. Siasat tersebut diambil dengan cara memasukkan warga rentan miskin ke dalam daftar BDT. Hal ini dilakukan agar sewaktu-waktu warga rentan miskin membutuhkan bantan dan subsidi negara mereka dapat mengaksesnya. Sehingga langkah tersebut mencegah mereka yang rentan miskin jatuh dibawah garis kemiskinan.

Alhasil, paradoksal pembangunan menjadi tampak, warga yang rentan miskin ini sesungguhnya hadir sebagai kelas menengah baru di desa. Mereka dapat mengakses subsidi negara dan bantuan publik manakala mereka membutuhkan biaya pendidikan kuliah atau biaya berobat pada saat diperlukan dengan cara "dimiskinkan" secara administratif. Sembari mereka melakukan mobilitas sosial, kualitas hidup mereka meningkat meski mereka "miskin".[]

\section{Daftar Pustaka}

Abrahamsen, Rita. 2000. Disciplining democracy: Development discourse and good governance in Africa. London: Zed Books.

Badan Pusat Statistik. 2018. Provinsi Daerah Istimewa Yogyakarta Dalam Angka 2018.

Badan Pusat Statistik. 2019. Kecamatan Dlingo Dalam Angka 2019.

Bogdan, Robert C., dan Sari Knopp Biklen. 1982. Qualitative Eesearch for Education: An Introduction to Theory and Practice. New York: Alien and Bacon Inc.

Burchell, Graham, Colin Gordon, and Peter Miller. 1991. The Foucault Effect: Studies in Governmentality with two Lectures by and an Interview with Michel Foucault. Chicago: Chicago University Press.

Candra, Sapto Andika. 2017. "DIY Paling Timpang Ekonominya Namun Paling Bahagia Penduduknya". Republika, 17 Juli 2017. https://www.republika.co.id/berita/nasional/daerah/17/07/17/ot86kp-diypaling-timpang-ekonominya-namun-paling-bahagia-penduduknya.

Cho, Hee-Yeon. 2008. "Democratization in Asia: Oligarchic Democracy and Democratic Oligarchy". Dalam States of Democracy: Oligarchic Democracies and Asian Democratization, edited by Cho, Hee-Yeon, Lawrence Surendra, and Eunhong Park, 3-22. Chennai: Earthworm Books.

Eko, Sutoro. 2015. “Pendampingan Desa”. Kompas, 2 Juli 2015. 
Escobar, Arturo. 1995. Encountering Development: The Making and Unmaking of the Third World. New Jersey: Pricenton University Press.

Ferguson, James. 1994. The Anti-Politics Machine: 'Development', Depoliticization, and Bureaucratic Power in Lesotho. University of Minessota Press.

Flynn, Thomas. 1994. "Foucault's Mapping History". Dalam The Cambridge Companion to Foucault, edited by Gary Gutting, 29-50. NY: Cambridge University Press.

Foucault, Michel. 1991. “Governmentality." Dalam The Foucault Effect: Studies in Governmentality edited by G. Burchell, C. Gordon, \& P. Miller, 87-104. Chicago: The University of Chicago Press.

Hariss, John. 2001. Depolitisizing Development: The World Bank and Social Capital. LeftWord Books.

Hadiz, Vedi \& Richard Robison (2013). The Political Economy of Oligarchy and the Reorganization of Power in Indonesia. In Journal Indonesia, No. 96, Cornell University Press

Hiariej, Eric, and Kristian Stokke. 2018. Politik Kewargaan di Indonesia. Yogyakarta: YOI dan Polgov UGM.

Li, Tania M. 2012. The Will To Improve: Perencanaan, Keuasaan, dan Pembangunan di Indonesia. Yogyakarta: Margin Kiri.

Pemerintah Desa Mangunan. 2018. Profil Desa Mangunan 2018.

Pemerintah Desa Mangunan. 2018. RPJM Desa Mangunan 2018-2024.

Rose, Nikolas. 1999. Governing the Soul: The Shaping of the Private Self. London: Routledge

Santoso, Purwo. 2010. "Securing The Pace And The Direction of Indonesian Democratization". Dalam Politik Kewargaan di Indonesia, edited by Eric Hiariej and Kristian Stokke. Yogyakarta: YOI dan Polgov, FISIPOL, UGM

Sekretariat Daerah Provonsi DIY. 2018. Laporan Keterangan Pertanggungjawaban Gubenur DIY Tahun 2018.

Stake, Robert E., 2005. "Qualitative Case Study". Dalam The Sage handbook of qualitative research, 3rd ed, edited by Norman K. Denzin and Yvonna S. Lincoln. Thousand Oaks, CA: Sage Publications.

Stoler, Ann Laura. 2002. Carnal knowledge and imperial power: race and the intimate in colonial rule. Berkeley, CA: University of California Press 
TNP2K. 2020. Basis Data Terpadu Desa Mangunan 2019.

Winters, Jeffrey A. 2014. "Oligarki dan Demokrasi di Indonesia”. Dalam Merancang Arah Baru Demokrasi: Indonesia Pasca Reformasi, edited by AE Priyono dan Usman Hamid. Jakarta: Kepustakaan Populer Gramedia.

Yin, Robert K. 1996. Studi Kasus, Desain dan Metode. Jakarta: Raja Grafindo Persada.

\section{Biografi Penulis}

Fatih Gama Abisono Nasution adalah dosen di Sekolah Tinggi Pembangunan Masyarakat Desa APMD, Yogyakarta, Indonesia. Minat kajian dan fokus risetnya berkaitan dengan governance dan politik pemerintahan desa.

Email: fatih.abisono@gmail.com 